\title{
Behavior Intention to Use Online Zakat: Application of Technology Acceptance Model with Development
}

\author{
Purwanto $^{1 *}$ Muhammad Sulthon $^{2}$ and Milna Wafirah ${ }^{3}$ \\ ${ }^{1,3}$ STAI Al Husain, Magelang \\ ${ }^{2}$ UIN Walisongo, Semarang
}

\begin{abstract}
Indonesia is one of the countries with the largest Muslim population in the world, but the level of zakat is not too high. This can be seen from the low amount of zakat that has been successful compared to the potential for zakat. In view of this fact, the Zakat Management Organization (OPZ) implements a digitalization strategy for collecting zakat funds, including the Magelang Regency. This study was conducted to understand the intention of the community/muzakki to pay zakat online. This study uses the Technology Acceptance Model (TAM) theoretical framework by adding a moderating variable to electronic word of mouth (eWOM). This study used a quantitative approach with 135 respondents. Data were collected randomly from the Internet (online). Structural equation modeling (SEM) and partial least squares (PLS) were used for data analysis. The findings of this study suggest that attitudes can be expressed by perceived ease of use, perceived usefulness, and electronic word of mouth (eWOM). Meanwhile, behavioral intention in this study proved to be reliable by electronic word of mouth (eWOM) and attitude. The results of the moderation effect test prove that electronic word of mouth (eWOM) in this study weakens the relationship between perceived ease of use (PEoU) and attitude. Electronic word of mouth (eWOM) can assess the relationship between perceived usefulness $(P U)$ and attitudes and behavioral intentions.
\end{abstract}

Keywords: eWOM; Perceived ease of use; Prceived usefulness; Attitude; dan Behavior intention.

*Corresponding author: purwanto@staia-sw.ac.id

Received: March 28, 2021; Accepted: May 05, 2021; Published: June 15, 2021

\begin{abstract}
Abstrak: Indonesia merupakan salah satu negara dengan jumlah penduduk Muslim terbesar di dunia, namun dalam pengumpulanzakat belum terlalu membanggakan. Hal ini dapat dilihat dari rendahnya jumlah zakat yang berhasil di himpun dibandingkan dengan potensi zakat. Melihat kenyataan ini maka Organisasi Pengelola Zakat (OPZ) menerapkan strategi digitalisasi dalam penghimpunan dana zakat termasuk di Kabupaten Magelang. Guna memahami niatmuzakki untukmembayar zakat secara online maka studi ini dilakukan. Studi ini menggunakan kerangka teori Technology Acceptance Model (TAM) dengan menambahakan variabel moderasi electronic word of mouth (eWOM). Studi ini dilakukan dengan pendekatan kuantitatif dengan jumlah responden penelitian sebanyak 135. Data penelitian dikumpulkan secara acak dengan menggunakan media internet (online). Analisis data menggunakan structural equation modeling (SEM) partial least
\end{abstract}


squares (PLS). Temuan studi ini menunjukkan bahwa sikap dapat dipengaruhi oleh kemudahan penggunaan yang dirasakan (PEoU), kegunaan yang dirasakan (PU) dan electronic word of mouth (eWoM). Sedangkan niat berperilaku dalam penelitian ini terbukti dapat dipengaruhi oleh electronic word of mouth (eWOM) dan sikap. Adapun hasil pengujian efek moderasi membuktikan bahwa electronic word of mouth (eWOM) pada penelitian ini justru melemahkan hubungan kemudahan penggunaan yang dirasakan (PEoU) degan sikap. Electronic word of mouth (eWOM) dapat memperkuat kegunaan yang dirasakan (PU) terhadap sikap dan niat berperilaku.

Kata kunci: eWOM; Kemudahan penggunaan; Kegunaan yang dirasakan; Sikap; dan Niat berperilaku

\section{INTRODUCTION}

Zakat (obligatory șadaqat) has been preached since the early period of Islam (the era of Prophet Muhammad SAW and Friends), both in the form of bil-lisan, dawah bil-kitabah, and dakwah bil-hal (Sulthon, 2015). This indicates that zakat is an aspect of Islamic teaching. Zakat is carried out not only as a form of obedience to Islamic teachings but also as a form of concern for fellow humans because zakat assets will be distributed evenly.Furthermore, in the economic sector, zakat distribution can reduce poverty and increase income and welfare (Beik \& Irawan, 2017; Islam \& Khan, 2019). It can be said that issuing zakat is not only a form of obedience to religious orders but also a form of social care.

Although zakat is a form of obedience to religious orders and a form of social concern, public awareness of paying zakat is still lacking. This can be seen from the low zakat funds collected compared to the potential zakat funds. The National Zakat Agency (BAZNAS) notes that the potential for zakat always increases.Even in 2019, the potential for zakat in Indonesia reached 485 trillion, but from that potential, the zakat fund that has been collected is only 8.2 trillion (Ichwan \& Ghofur, 2020). As a result, BAZNAS has prepared a number of strategies to maximize the potential of zakat in Indonesia. One of them is the digitization of zakat management (Puskas BAZNAS, 2020).The digitization of zakat management in Indonesia is shown in Figure 1.

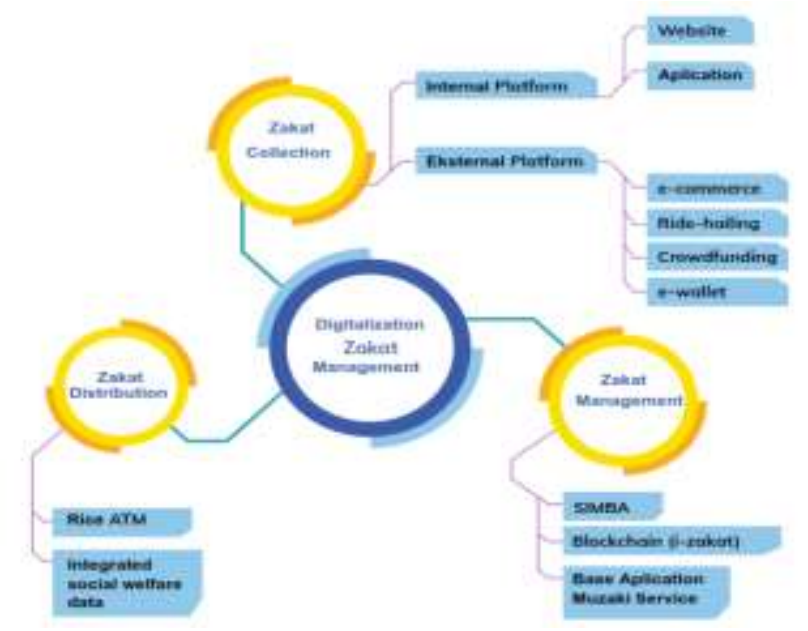

Figure1. Digitalization of Zakat Management in Indonesia 
Figure 1 shows that in the aspect of collecting zakat funds, BAZNAS has made digitalization efforts by developing internal and external platforms. The development of the internal platform is carried out by developing website-based services by the Zakat Management Organization (OPZ). Apart from website development, OPZ has also developed Android-based applications such as the BAZNAS application, LAZ Muhammadiyah, NU Care, and LAZ Initiative Zakat Indonesia.In addition, several OPZs have also innovated the receipt of zakat payments through automatic M-Cash machines (Puskas BAZNAS, 2020). In addition to developing internal platforms, OPZ also collaborates with external platform providers to provide digital services for zakat payments, such as ecommerce, crowdfunding, and ride-hailing dan e-wallet (Puskas BAZNAS, 2020). OPZ also collaborates with the Kitabisa.com crowdfunding to receive ZIS funds from donors and distribute them to those who are entitled (Puskas BAZNAS, 2020).This illustration shows that the OPZ in Indonesia digitalized a strategy for collecting zakat funds. With this digitalization, it is hoped that it can increase the number of successful zakat funds from the people of Indonesia and, ultimately, improve the welfare of the community.

Digitalization in the collection of zakat seems appropriate, given the high use of ecommerce in Indonesia, which is the highest in the world (GlobalWebIndex, 2019). Even e-commerce users in Indonesia 90\% of its users are between 16 and 64 years old (Dirgantari, Hidayat, Mahphoth, \& Nugraheni, 2020). This further reinforces that in the next few years, community activities for online transactions will become a trend in Indonesia, including zakat. Therefore, this study intends to examine how people's behavior in using technology to pay zakat online.A study conducted by Utami, Suryanto, Nasor, \& Ghofur (2020) proves that digitalization has an effect on the potential for collecting zakat funds. This indicates that the digitalization strategy for collecting zakat will increase the amount of zakat collection by OPZ. The technology acceptance model (TAM), developed by Davis (1989), is commonly used to predict technology usage behavior. TAM is an adaptation of Theory of Reasoned Action (TRA) (Al-Maghrabi \& Dennis, 2011; Celik, 2011; Ma, Gam, \& Banning, 2017). TRA is a theory that is often used in research, while TAM was developed for research related to technology acceptance (Ma et al., 2017).

The TAM was originally developed to predict the acceptance of information systems in the workplace (Lee, Fiore, \& Kim, 2006; Ma, Gam, \& Banning, 2017), however, in its development TAM has also been widely used to predict people's decisions to pay zakat through Gopay (Ichwan \& Ghofur, 2020). TAM is also used to conduct online philanthropy payment behavior analysis (Usman, Mulia, Chairy, \& Widowati, 2020). In addition, Roziq, Wijayanti, and Irmadariyani (2020)used TAM to analyze information systems in the management of zakat at BAZNAS, Niswah, Mutmainah, and Legowati (2019) used TAM to analyze the intention of millennial Muslims to donate using the fintech platform.

The description above shows that empirically, the TAM has been widely used to predict the behavior of using technology for transactions, including online zakat payments.Conceptually, TAM comprises two independent variables: perceived usefulness (PU) and perceived ease of use (PEoU). PU affects attitudes and 
behavioral intentions. Meanwhile, PEoU affects attitudes, and attitudes affect behavioral intentions (Fathema, Shannon, \& Ross, 2015; Ma et al., 2017; Vijayasarathy, 2004). Intention to behave in turn influences actual behavior (Pikkarainen, Pikkarainen, Karjaluoto, \& Pahnila, 2004).

Perceived usefulness (PU) is the refers to the extent to which a person believes that the adoption of a particular system will improve performance in his work (Fathema et al., 2015; He, Chen, \& Kitkuakul, 2018; Venkatesh, Morris, Davis, \& Davis, 2003). Sementara perceived ease of use (PEoU) is the extent to which one believes that the adoption of a system does not require a large amount of effort (Fathema et al., 2015; He et al., 2018; Venkatesh et al., 2003) in the sense that a system is easy to use. Attitude refers to an evaluation of whether the behavior is beneficial or not (Ajzen, 1991), negative or positive (Ziadat, 2015) and like or dislike behavior (Eagly \& Chaiken, 2007) and has an influence on the intention to behavior (Purwanto, 2021). Intention is defined as a plan to carry out a behavior (Fathema et al., 2015). Either attitude or intention in TAM is influenced byperceived usefulness (PU) and perceived ease of use (PEoU).

Although the TAM is used to predict the behavior of technology use, inconsistencies remain. The research conducted by Darsono (2005) and Nguyen et al. (2019) for example, there is no evidence that perceived usefulness (PU) affects the intention to use technology. The results of research conducted by Lee et al. (2011) and Niswah et al. (2019) also prove that perceived usefulness (PU) has no effect on attitudes. Niswah et al. (2019) found no evidence that perceived ease of use (PEoU) affects attitudes. Even in the early TAM model, attitudes had a weak influence on intention (Amoroso \& Hunsinger, 2009).Niswah et al. (2019) also did not find that attitudes had no effect on the intention to use technology.

Considering the inconsistent research results in the TAM model, it is necessary to develop the TAM model. In this study, eWOM was added as a moderating variable. Moderating variables strengthen or weaken the relationship between variables (Farooq \& Vij, 2017). The addition of moderating variables can be considered if there are inconsistent results in a model or if the relationship between variables is weak (Kim, Kaye, \& Wright, 2001). Therefore, the addition of eWOM as a moderating variable was appropriate.

eWOM is all informal communication directed at consumers through internet-based technology regarding the characteristics of certain services (Chen, Nguyen, Klaus, \& Wu, 2015). Meanwhile, Hidayanto, Ovirza, Anggia, Budi, \& Phusavat (2017) define eWOM as a positive or negative statement by users regarding a technology. Therefore, eWOM in the context of online zakat payments is a form of positive or negative statement about an activity after it completes the transaction process on the online zakat application.

Through eWOM, muzakki can find information about the services provided by the OPZ, whether as expected, channeled to the right party, and so on. Therefore, muzakkican use eWOM to decide whether he will distribute his zakat online or not. The study results by Cheung, Lee, \& Thadani (2009) shows that positive eWOM can improve integrity and attitude (Cheung et al., 2009). A study conducted by Kudeshia and Kumar (2017) proved that eWOM can positively affect attitudes toward brands and affect intentions. 
Thus, eWOMplays an important role in the TAM. A person can accept the online zakat application well, but because he gets a negative eWOM, he will cancel his intention to make zakat payments online or his attitude toward the online zakat application becomes negative. Therefore, this study intends to examine how people's behavior to pay zakat online using the TAM model and add a moderating variable, namely eWOM.

\section{RESEARCH METHODS}

\section{Population and Sample}

The population in this study was people in Magelang Regency who were selected randomly. This means that all people in Magelang Regency have the same opportunity to become research samples. The questionnaire was distributed to all regions of the Magelang Regency online from December 2020 to March 2021. Theoretically, SEM analysis requires a sample of at least 100-200 samples (Kusnendi, 2005). From the results of the distribution of the questionnaire, the data collected were 135 respondents, so the sample size was deemed adequate.

\section{Questionnaire Instruments and Design}

A quality questionnaire was used to collect the data in this study using a questionnaire. To ensure the quality of the questionnaire used, the researcher adopted a questionnaire that had been used by previous researchers by modifying it according to the context of this study. Perceived usefulness (PU) and perceived Ease of Use (PEoU) variables in this study adopted a questionnaire used by Leong, Ibrahim, Dalvi-Esfahani, Shahbazi, \& Nilashi, (2018); Usman et al., (2020) with the number of statements each of the four statement items. The AT in this study adopted a questionnaire that was used by Arora and Aggarwal (2018) and Usman et al. (2020) with the number of statements for each of the four statements. The statements on the behavioral intention (BI) variable were four items adopted from the items used by Arora and Aggarwal (2018), Leong et al. (2018), and Usman et al. (2020). The electronic word of mouth (eWOM) variable in this study was measured using six statements adopted from the study by Hidayanto et al. (2017) and Jalilvand and Samiei (2012).

Thus, there are five variables with 22 statements that describe all the research variables. The research questionnaire was distributed online to respondents. All statements were measured using a five-point Likert scale. Answer 1 as "strongly disagree", answer 2 as "disagree", answer 3 "Neutral, answer 4 "agree"and answer 5 "strongly agree" (Memon, Azhar, Haque, \& Bhutto, 2019).

\section{Construct Validityand Reliability}

Questionnaires are important for quantitative research (Purwanto, 2018). Therefore, a quality questionnaire was required. The quality of a questionnaire can be determined by looking at the level of validity and reliability. The validity test in this study was determined using convergent and discriminant validity. A construct can meet the criteria for convergent validity if it has a factor loading value greater than 0.7, composite reliability (CR) greater than 0.7 , average variance extracted (AVE) value greater than 0.5 , and composite reliability (CR) greater than 0.7 (Hair, Ringle, \& Sarstedt, 2011; Zhang et al., 2014). 
The validity test with the discriminant validity criteria in this study was determined by examining the cross-loading value and the Fornell-Larcker criterion. The crossloading of an indicator in a variable can be fulfilled if each indicator has a higher value than the other variables' indicators (Chawla \& Joshi, 2018). The discriminant validity with the Fornell-Larcker criterion can be fulfilled if the correlation between variables with squared AVE is higher than that with other variables (Chawla \& Joshi, 2018). The next quality questionnaire criterion was that it met the reliability criteria. An indicator is said to be reliable if it has a Cronbach $\alpha$ value that has a value greater than 0.6 then the indicators used are reliable (Gottems, Carvalho, Guilhem, \& Pires, 2018).

\section{Data Analysis}

To perform data analysis, this study uses a variant-based structural equation model (SEM) analysis, also known as partial least squares (PLS) (Sholihin \& Ratmono, 2013). The use of SEM PLS in this study is because the indicators used are relatively unstable, and PLS SEM can be used on data that are not normally distributed (Henseler, Ringle, \& Sinkovics, 2009).

\section{Research Model and Hypotheses}

The research model used in this study is shown in Figure 2. The proposed hypothesis is as follows.

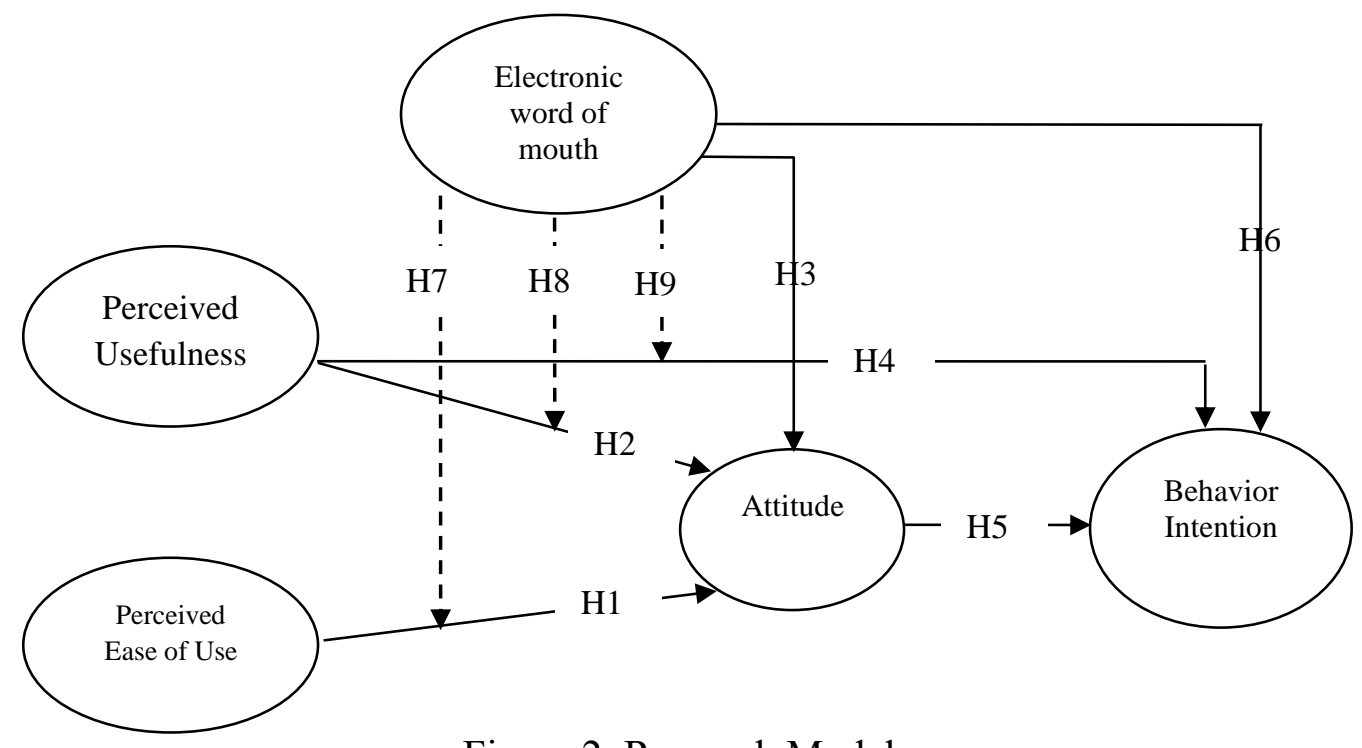

Figure 2. Research Model

From Figure 2, the hypothesis proposed in this study are as follows:

H1: Perceived ease of use has a positive effect on attitude.

H2: Perceived usesfulness has a positive effect on attitude.

H3: Electronic word of mouth has a positive effect on attitude.

H4: Perceived usesfulness has a positive effect on behavior intention.

H5: Attitude has a positive effect on behavior intention.

H6: Electronic word of mouth has a positive effect on behavior intention. 
H7: Electronic word of mouth moderates the relationship between perceived. ease of use to attitude.

H8: Electronic word of mouth moderates the relationship between perceived usesfulness terhadap attitude.

H9: Electronic word of mouth moderates the relationship between perceived usesfulness terhadap behavior intention.

\section{RESULTS AND DISCUSSION}

\section{Demographics of Respondent}

From the results of distributing questionnaires online, the data obtained were obtained from 135 respondents. This means that this number is considered sufficient for analysis using SEM-PLS. In accordance with the results of the data collection, it was discovered that the majority (54.8\%) of the respondents were female. Detailed information concerning the demographics of the respondents is shown in Table 1.

Table 1. Demographics of Respondent

\begin{tabular}{clcc}
\hline Description & \multicolumn{1}{c}{ Criteria } & N & Presentation \\
\hline \multirow{2}{*}{ Sex } & Male & 61 & 45.2 \\
& Female & 74 & 54.8 \\
& < 25 years & 66 & 48.9 \\
& 26-30 years & 24 & 17.8 \\
& 31-35years & 25 & 18.5 \\
& 36-40years & 11 & 8.1 \\
& > 40 years & 9 & 6.7 \\
& Teacher & 18 & 13.3 \\
& Lecturer & 13 & 9.6 \\
& Farmer & 0 & 0.0 \\
& Pedagang & 6 & 4.4 \\
& Private employees & 31 & 23.0 \\
& Entrepreuneurs & 2 & 1.5 \\
& Student & 45 & 33.3 \\
& Other & 20 & 14.8 \\
\hline
\end{tabular}

Before testing the model, we first tested whether there was bias in the data collection. Whether there is bias in data collection, the common method variance (CMV) test (Hossen, Chan, \& Hasan, 2020). In this study, the CMV test used the correlation matrix procedure (Tehseen, Ramayah, \& Sajilan, 2017). An indication of the presence or absence of bias can be seen from the high correlation between the latent variables that reaches $0.9(\mathrm{r}>0.9)$. The results of the correlation test showed that there were no latent variables that were correlated more than 0.90 , as shown in Table 2 . Thus, there were no bias problems in this study. 


\begin{tabular}{lccccc}
\hline & AT & BI & PEoU & PU & eWOM \\
\hline AT & 1 & & & & \\
BI & 0.770 & 1 & & & \\
PEoU & 0.707 & 0.616 & 1 & & \\
PU & 0.738 & 0.614 & 0.746 & 1 & \\
eWOM & 0.654 & 0.602 & 0.632 & 0.660 & 1 \\
\hline
\end{tabular}

Testing the hypothesis in this study using structural equation modeling analysis with tools in the form of Smart-PLS software (version 3.0). In the SEM analysis, there are two stages: testing the structural model and testing the research hypothesis.

\section{Measurement Model}

The measurement model is basically carried out to determine the validity and reliability of each construct of the research variables. In the SEM-PLS analysis, there are two ways to determine the level of construct validity: convergent and discriminant validity. From the test results shown in Table 3, all the constructs that form variables have factor loadings greater than 0.7 , composite reliability (CR) greater than 0.7, and average variance extracted (AVE) value greater than 0.5 . Thus, the research variables met the criteria for convergent validity.

Table 3. Measurement Model: Factor Loading, Alpha, CR, and AVE

\begin{tabular}{|c|c|c|c|c|c|}
\hline Variable & Item & Loadings & Cronbach $\alpha$ & $\mathrm{CR}$ & AVE \\
\hline \multirow[t]{4}{*}{ Attitude (AT) } & AT1 & 0.846 & 0.873 & 0.913 & 0.726 \\
\hline & AT2 & 0.867 & & & \\
\hline & AT3 & 0.785 & & & \\
\hline & AT4 & 0.904 & & & \\
\hline \multirow[t]{4}{*}{ Behavior Intention (BI) } & BI1 & 0.916 & 0.920 & 0.944 & 0.809 \\
\hline & $\mathrm{BI} 2$ & 0.920 & & & \\
\hline & $\mathrm{BI} 3$ & 0.929 & & & \\
\hline & BI4 & 0.829 & & & \\
\hline \multirow{4}{*}{$\begin{array}{l}\text { Perceived } \\
\text { (PEoU) }\end{array}$} & PEoU1 & 0.882 & 0.938 & 0.956 & 0.843 \\
\hline & PEoU2 & 0.920 & & & \\
\hline & PEoU3 & 0.946 & & & \\
\hline & PEoU4 & 0.925 & & & \\
\hline \multirow[t]{3}{*}{ Perceived Usefulness (PU) } & PU1 & 0.901 & 0.865 & 0.909 & 0.715 \\
\hline & PU2 & 0.895 & & & \\
\hline & PU3 & 0.739 & & & \\
\hline \multirow{7}{*}{$\begin{array}{l}\text { Electronic word of mouth } \\
\text { (eWOM) }\end{array}$} & PU4 & 0.836 & & & \\
\hline & eWOM1 & 0.816 & 0.910 & 0.931 & 0.691 \\
\hline & eWOM2 & 0.891 & & & \\
\hline & eWOM3 & 0.815 & & & \\
\hline & eWOM4 & 0.879 & & & \\
\hline & eWOM5 & 0.803 & & & \\
\hline & eWOM6 & 0.779 & & & \\
\hline
\end{tabular}

note. $A V E=$ Average Variance Extracted and $C R=$ Composite Reliability. 
The results of the validity test based on the discriminant validity criteria in this study were assessed using the cross-loading value and the Fornell-Larcker criterion (Hair et al., 2011). The results shown in Table 4 show that all loading values for each indicator have a higher value when compared to the loading values for the other variables. Meanwhile, the results of discriminant validity testing based on the Fornell-Larcker criterion showed that the resulting correlation was higher than the correlation of other variables. The test results in Table 5 show that all the square roots of AVE (diagonal values) are greater than the correlation coefficient between constructs, so that the discriminant validity has been fulfilled.

Tabel 4. Outer Loading Factor

\begin{tabular}{cccccc}
\hline Indikator & AT & BI & PEoU & PU & eWOM \\
\hline AT1 & 0.846 & 0.613 & 0.576 & 0.701 & 0.644 \\
AT2 & 0.867 & 0.690 & 0.600 & 0.537 & 0.465 \\
AT3 & 0.785 & 0.626 & 0.553 & 0.546 & 0.452 \\
AT4 & 0.904 & 0.694 & 0.672 & 0.716 & 0.650 \\
BI1 & 0.665 & 0.916 & 0.559 & 0.548 & 0.533 \\
BI2 & 0.692 & 0.920 & 0.531 & 0.588 & 0.554 \\
BI3 & 0.703 & 0.929 & 0.571 & 0.542 & 0.538 \\
BI4 & 0.705 & 0.829 & 0.552 & 0.527 & 0.537 \\
PEoU1 & 0.647 & 0.566 & 0.882 & 0.784 & 0.588 \\
PEoU2 & 0.636 & 0.527 & 0.920 & 0.630 & 0.586 \\
PEoU3 & 0.671 & 0.615 & 0.946 & 0.691 & 0.578 \\
PEoU4 & 0.640 & 0.551 & 0.925 & 0.633 & 0.569 \\
PU1 & 0.593 & 0.478 & 0.586 & 0.901 & 0.523 \\
PU2 & 0.661 & 0.545 & 0.635 & 0.895 & 0.592 \\
PU3 & 0.639 & 0.612 & 0.717 & 0.739 & 0.508 \\
PU4 & 0.577 & 0.401 & 0.550 & 0.836 & 0.603 \\
eWOM1 & 0.494 & 0.458 & 0.512 & 0.571 & 0.816 \\
eWOM2 & 0.602 & 0.600 & 0.538 & 0.567 & 0.891 \\
eWOM3 & 0.483 & 0.442 & 0.471 & 0.524 & 0.815 \\
eWOM4 & 0.607 & 0.491 & 0.564 & 0.601 & 0.879 \\
eWOM5 & 0.552 & 0.511 & 0.587 & 0.552 & 0.803 \\
eWOM6 & 0.506 & 0.482 & 0.473 & 0.474 & 0.779 \\
\hline
\end{tabular}

Tabel 5. Fornell \& Larcker Criterion Values

\begin{tabular}{lccccc}
\hline & AT & BI & PEoU & PU & eWOM \\
\hline Attitude (AT) & $\mathbf{0 . 8 5 2}$ & & & & \\
Behavior Intention (BI) & 0.770 & $\mathbf{0 . 8 9 9}$ & & & \\
Perceived Ease of Use (PEoU) & 0.707 & 0.616 & $\mathbf{0 . 9 1 8}$ & & \\
Perceived Usefulness (PU) & 0.738 & 0.614 & 0.746 & $\mathbf{0 . 8 4 6}$ & \\
Electronic word of mouth (eWOM) & 0.654 & 0.602 & 0.632 & 0.660 & $\mathbf{0 . 8 3 1}$ \\
\hline
\end{tabular}

Meanwhile, the test results in Table 3 show that all research variables have a Cronbach's $\alpha$ value greater than 0.6 , so that the research variables met the reliability 
criteria. Thus, the variables in this study were measured using constructs that met the validity and reliability criteria.

\section{Structural Model}

To increase the accuracy of the estimation, the structural model in this study was carried out using a bootstrap procedure with 10,000 repeat samples (Streukens \& Leroi-Werelds, 2016). With bootstrap testing, all relationships between the research variables, beta, and $t$ values can be estimated. Table 6 presents the estimation results.

Tabel 6. Structural Model

\begin{tabular}{|c|c|c|c|c|c|c|c|c|c|}
\hline & Relationship & $\begin{array}{l}\text { Std. } \\
\text { Beta }\end{array}$ & $\begin{array}{c}\text { Std. } \\
\text { error }\end{array}$ & T-value & $\mathbf{P}$ & Results & $\mathbf{R}^{2}$ & $\mathbf{Q}^{2}$ & $\mathbf{f}^{2}$ \\
\hline $\mathrm{H}_{1}$ & PEoU $->$ AT & 0.301 & 0.082 & $3.679^{* * * *}$ & 0.000 & $\begin{array}{c}\text { not } \\
\text { rejected }\end{array}$ & & & 0.086 \\
\hline $\mathrm{H}_{2}$ & $\mathrm{PU} \rightarrow \mathrm{AT}$ & 0.401 & 0.073 & $5.467^{* * *}$ & 0.000 & $\begin{array}{c}\text { not } \\
\text { rejected }\end{array}$ & 0.626 & 0.445 & 0.147 \\
\hline $\mathrm{H}_{3}$ & eWOM $->$ AT & 0.209 & 0.070 & $2.999^{* * *}$ & 0.000 & $\begin{array}{c}\text { not } \\
\text { rejected }\end{array}$ & & & 0.071 \\
\hline $\mathrm{H}_{4}$ & $\mathrm{PU}->\mathrm{BI}$ & 0.078 & 0.079 & 0.983 & 0.326 & rejected & & & 0.001 \\
\hline $\mathrm{H}_{5}$ & $\mathrm{AT}->\mathrm{BI}$ & 0.621 & 0.082 & $7.596^{* * *}$ & 0.000 & $\begin{array}{c}\text { not } \\
\text { rejected }\end{array}$ & 0.610 & 0.494 & 0.423 \\
\hline $\mathrm{H}_{6}$ & eWOM ->BI & 0.212 & 0.080 & $2.650^{* * *}$ & 0.008 & $\begin{array}{c}\text { not } \\
\text { rejected }\end{array}$ & & & 0.033 \\
\hline
\end{tabular}

Table 6 shows that Hypothesis $1(\mathrm{H} 1)$ the variable of perceived ease of use (PEoU) on attitude has a value $\left(\beta=0.301, t=3.679, f^{2}=0.086\right)$, so it can be concluded that perceived ease of use (PEoU) has a significant effect on attitude. This study supports the results of research conducted by (Usman et al., 2020) which proves that perceived ease of use (PEoU) has a significant effect on attitude. Thus, the attitude to make zakat payments online can be determined by the perception of ease by muzakki.

The results of testing Hypothesis $2(\mathrm{H} 2)$, the variable of perceived usefulness (PU) on attitude, has a value $\left(\beta=0.401, t=5.467, f^{2}=0.147\right)$. Thus, it can be concluded that perceived usefulness (PU) has a significant effect on attitude. This indicates that muzakki's attitude toward online zakat payments can be determined by the perception of whether or not the online zakat application is easy. The results of this study support the research conducted by Usman et al. (2020), which also proves that perceived usefulness (PU) has a significant effect on attitude.

The results of testing hypothesis 3 (H3), the variable of electronic word of mouth (eWOM) on attitudehas a value $\left(\beta=0.209, t=2.999, f^{2}=0.071\right)$, indicating that electronic word of mouth (eWOM) has a significant positive effect on attitude. Thus, this study supports the results of research conducted by Rachbini and Agustina (2019), Madjid, Ma'ruf, Ibrahim, \& Havizatun (2018), and Mahaputra and Setiawan (2019), which proves that electronic word of mouth (eWOM) has an influence on attitude. 
While testing hypothesis 4 (H4), PU on behavior intention has a value $(\beta=0.078, t$ $\left.=0.983, f^{2}=0.001\right)$, so it can be concluded that PU does not have a significant effect on behavior intention. The results of this study are in line with those ofMuslichah (2018), which also proves that perceived usefulness (PU) does not affect behavioral intention. Thus, there is an indication that the effect of perceived usefulness (PU) on behavioral intention is an indirect effect. However, this research does not support the results of the research conducted by Karmanto and Baskoro (2020), Sulaeman (2020), Karmanto, Mahri, and Nurasyiah (2021); Kholid (2018) and Niswah et al. (2019), which proves that perceived usefulness (PU) has a significant effect on behavioral intention.

The results of testing hypothesis 5 (H5) that the variable of attitude on behavioral intention has a value $\left(\beta=0.621, t=7.596, f^{2}=0.423\right)$, so it can be concluded that attitude has an influence on behavioral intention. The results of this study are in line with the results of the studies conducted by Usman et al. (2020) and Yusfiarto, Setiawan, and Nugraha (2020), which also proves that attitude has a significant influence on behavioral intention.

The results of testing hypothesis 5 (H6), the variable of electronic word of mouth (eWOM) on behavioral intention, has a value $\left(\beta=0.212, t=2.650, f^{2}=0.033\right)$. So it can be concluded that electronic word of mouth (eWOM) is proven to have a significant positive effect on behavior intention. The results of this study are in line with the research conducted by Roy, Datta, and Mukherjee (2019) and Febrian and Fadly (2021), which also proves that electronic word of mouth (eWOM) has a significant positive effect on behavioral intention.

In general, the test results prove that this study does not rejectfive hypotheses $\left(\mathrm{H}_{1}\right.$, $\mathrm{H}_{2}, \mathrm{H}_{3}, \mathrm{H}_{5}$, and $\left.\mathrm{H}_{6}\right)$ andrejectedonehypothesis $\left(\mathrm{H}_{4}\right) . \mathrm{R}^{2}$ of 0.626 indicates that $62.2 \%$ of the variation in attitudes can be trusted by perceived ease of use (PEoU), perceived usefulness (PU), and electronic word of mouth (eWOM). Meanwhile, behavioral intention has an $\mathrm{R}^{2}$ of 0.610 , which indicates that attitudes, perceived usefulness (PU), and electronic word of mouth (eWOM) can explain $61.0 \%$ of the variation in behavioral intentions.

\section{Moderating Analysis}

The bootstrapping method can be used to analyze the indirect effects of the bootstrapping method (Hossen et al., 2020). The results of testing the mediating effects of the attitude variables are presented in Table 8.

Table 7.Moderating Analysis

\begin{tabular}{clccccc}
\hline Relationship & $\begin{array}{c}\text { Std. } \\
\text { Beta }\end{array}$ & $\begin{array}{c}\text { Std. } \\
\text { error }\end{array}$ & $\begin{array}{c}\text { T- } \\
\text { value }\end{array}$ & P & Results \\
\hline $\mathrm{H}_{7}$ & eWOM*PEoU -> AT & -0.106 & 0.061 & $1.743^{*}$ & 0.082 & Not rejected \\
$\mathrm{H}_{8}$ & eWOM *PU -> AT & 0.112 & 0.060 & $1.879^{*}$ & 0.061 & Not rejected \\
$\mathrm{H}_{9}$ & eWOM *PU ->BI & 0.100 & 0.038 & $2.615^{* * *}$ & 0.009 & Not rejected \\
\hline Note: $* * *)$ significant level<99\%; **) significant level<95\%; & significant level<90\%. &
\end{tabular}

The moderation effect test results in Table 8 prove that eWOM *PEoU $\rightarrow$ AT $(\beta=-$ $0.106, p<0.1)$. However, the resulting $\beta$ value is negative in meaning electronic word of mouth (eWOM) in this study, which weakens the ease of use (PEoU) relationship 
to attitude, but the level of significance is at the $90 \%$ level. Electronic word of mouth (eWOM)can weaken the relationship between ease of use (PEoU) and attitude can occur when Muzaki receives negative comments about the online zakat payment application. As for eWOM*PU $\rightarrow$ AT $(\beta=0.112, p<0.1)$. The resulting $\beta$ value is positive, meaning that electronic word of mouth (eWOM) can strengthen the perceived usefulness (PU) relationship with attitude with a significance level of $<90 \%$. For eWOM*PU $->$ BI $(\beta=0.100, p<0.05$, significant at the $95 \%$ level. This means that electronic word of mouth (eWOM) can strengthen the relationship between perceived usefulness (PU) and behavioral intention, because the resulting $\beta$ value is positive.

\section{CONCLUSION}

In general, the results of hypothesis testing prove that perceived ease of use (PEoU), perceived usefulness (PU), and electronic word of mouth (eWOM) significantly affect attitude. Meanwhile, behavior intention in this study is statistically proven to be influenced by attitude and electronic word of mouth (eWOM). An interesting finding in this study is that perceived usefulness (PU) is not proven to have an influence on behavioral intention. The results of testing the moderating effect on proving that electronic word of mouth (eWOM) in this study weakens the relationship between ease of use (PEoU) and attitude. Meanwhile, electronic word of mouth (eWOM) can strengthen the relationship between perceived usefulness (PU) and attitude. Furthermore, the result s of testing the moderation effect indicate that electronic word of mouth (eWOM) can strengthen the relationship between perceived usefulness (PU) and behavioral intention.

\section{REFERENCES}

Al-Maghrabi, T., \& Dennis, C. (2011). What Drives Consumers' Continuance Intention to e-shopping?: Conceptual Framework and Managerial Implications in the Case of Saudi Arabia. International Journal of Retail and Distribution Management, 39(12), 899-926. https://doi.org/10.1108/09590551111183308

Amoroso, D. L., \& Hunsinger, S. (2009). Measuring the Acceptance of Internet Technology by Consumers. International Journal of E-Adoption, 1(3), 48-81. https://doi.org/10.4018/jea.2009092903

Arora, N., \& Aggarwal, A. (2018). The Role of Perceived Benefits in Formation of Online Shopping Attitude Among Women Shoppers in India. South Asian Journal of Business Studies, 7(1), 91-110. https://doi.org/10.1108/SAJBS-042017-0048

Beik, I. S., \& Irawan, T. (2017). Dampak zakat terhadap kemiskinan dan kesejahteraan mustahik (Kasus: BAZNAS provinsi Jawa Tengah). AlMuzara'ah, 5(1), 37-50. https://doi.org/https://doi.org/10.29244/jam.5.1.3750

Celik, H. (2011). Influence of Social Norms, Perceived Playfulness and Online Shopping Anxiety on Customers' Adoption of Online Retail Shopping: An Empirical Study in the Turkish Context. International Journal of Retail \& Distribution Management, 39(6), 390-413. 
https://doi.org/10.1108/02656710210415703

Chawla, D., \& Joshi, H. (2018). Consumer attitude and intention to adopt mobile wallet in India - An empirical study. International Journal of Bank Marketing, 37(7), 1590-1618.

Chen, C. H., Nguyen, B., Klaus, P. "Phil," \& Wu, M. S. (2015). Exploring Electronic Word-of-Mouth (eWOM) in The Consumer Purchase DecisionMaking Process: The Case of Online Holidays - Evidence from United Kingdom (UK) Consumers. Journal of Travel and Tourism Marketing, 32(8), 953-970. https://doi.org/10.1080/10548408.2014.956165

Cheung, C. M. K., Lee, M. K. O., \& Thadani, D. R. (2009). The Impact of Positive Electronic Word of Mouth on Consumer Online Purchasing Decision. In Visioning and Engineering the Knowledge Society: A Web Science Perspective: Second World Summit on the Knowledge Society (Vol. 5736, hal. 501-510). https://doi.org/10.1007/978-3-642-04754-1_51

Darsono, L. I. (2005). Examining Information Technology Acceptance by Individual Professionals. Gadjah Mada International Journal of Business, 7(2), 155-178. https://doi.org/10.22146/gamaijb.5576

Davis, F. D. (1989). Perceived usefulness, perceived ease of use, and user acceptance of information technology. MIS Quarterly, 13(3), 319-340. https://doi.org/10.5962/bhl.title.33621

Dirgantari, P. D., Hidayat, Y. M., Mahphoth, M. H., \& Nugraheni, R. (2020). Level of Use and Satisfaction of E-Commerce Customers in Covid-19 Pandemic Period: An Information System Success Model (ISSM) Approach. Indonesian Journal of Science \& Technology, 5(2), 86-95. https://doi.org/https://doi.org/10.17509/ijost.v5i2.24617

Eagly, A. H., \& Chaiken, S. (2007). The Advantages of An Inclusive Definition of Attitude. Social Cognition, 25(5), 582-602.

Farooq, R., \& Vij, S. (2017). Moderating Variables in Business Research. The IUP Journal of Business Strategy, 14(4), 34-54. https://doi.org/https://ssrn.com/abstract=3219666

Fathema, N., Shannon, D., \& Ross, M. (2015). Expanding The Technology Acceptance Model (TAM) to Examine Faculty Use of Learning Management Systems (LMSs) In Higher Education Institutions. MERLOT Journal of Online Learning and Teaching, 11(2), 210-232.

Febrian, A., \& Fadly, M. (2021). The Impact of Customer Satisfaction with EWOM and Brand Equity on E-Commerce Purchase Intention in Indonesia Moderated by Culture. Binus Business Review, 12(1), 41-51. https://doi.org/10.21512/bbr.v12i1.6419

Ghozali, I., \& Latan, H. (2015). Partial Least Square Konsep, Teknik, dan Aplikasi Menggunakan Program SmartPLS 3.0 untuk Penelitian Empiris. Semarang: Badan Penerbit Universitas Diponegoro.

GlobalWebIndex. (2019). Digital 2019 Spotliht: Ecommerce in Indonesia. Diambil dari https://datareportal.com/reports/digital-2019-ecommerce-in-indonesia

Gottems, L. B. D., Carvalho, E. M. P. De, Guilhem, D., \& Pires, M. R. G. M. P. (2018). Good Practices in Normal Childbirth: Reliability Analysis of an Instrument by Cronbach's Alpha. Revista Lationo-Americana de Efermagem, 
26(3), 1-8. https://doi.org/10.1590/1518-8345.2234.3000

Hair, J. F., Ringle, C. M., \& Sarstedt, M. (2011). PLS-SEM: Indeed a silver bullet. Journal of Marketing Theory and Practice, 19(2), 139-152. https://doi.org/10.2753/MTP1069-6679190202

He, Y., Chen, Q., \& Kitkuakul, S. (2018). Regulatory Focus and Technology Acceptance: Perceived Ease of use and Usefulness as efficacy. Cogent Business and Management, 5(1), 0-22. https://doi.org/10.1080/23311975.2018.1459006

Henseler, J., Ringle, C., \& Sinkovics, R. (2009). The use of partial least squares path modeling in international marketing. Advances in International Marketing, 20, 277-319. https://doi.org/https://doi.org/10.1108/S14747979(2009)0000020014

Hidayanto, A. N., Ovirza, M., Anggia, P., Budi, N. F. A., \& Phusavat, K. (2017). The Roles of Electronic Word of Mouth and Information Searching in the Promotion of a New E-commerce Strategy: A case of Online Group Buying in Indonesia. Journal of Theoretical and Applied Electronic Commerce Research, 12(3), 69-85. https://doi.org/10.4067/S0718-18762017000300006

Hossen, M. M., Chan, T. J., \& Hasan, N. A. M. (2020). Mediating role of job satisfaction on internal corporate social responsibility practices and employee engagement in higher education sector. Contemporary Management Research, 16(3), 207-227. https://doi.org/10.7903/CMR.20334

Ichwan, A., \& Ghofur, R. A. (2020). Pengaruh technology acceptance model terhadap keputusan muzakki membayar zakat melalui fintech gopay. Jurnal Ilmiah Ekonomi Islam, 6(2), 129-135. https://doi.org/10.29040/jiei.v6i2.1011

Islam, M. T., \& Khan, M. T. A. (2019). Factors influencing the adoption of crowdfunding in Bangladesh: a study of start-up entrepreneurs. Information Development, $37(1)$

72-89. https://doi.org/https://doi.org/10.1177/0266666919895554

Jalilvand, M. R., \& Samiei, N. (2012). The impact of Electronic Word of Mouth on a Tourism Destination Choice. Internet Research, 22(5), 591-612. https://doi.org/10.1108/10662241211271563

Karmanto, G. D., \& Baskoro, B. D. (2020). Penggunaan platform crowdfunding dalam menyalurkan zakat, infaq, dan shadaqah (zis): studi intensi masyarakat. Jurnal Ekonomi dan Manajemen, 2(2), 1-15.

Karmanto, G. D., Mahri, A. J. W., \& Nurasyiah, A. (2021). Society 's intention in distribution of zakat, infaq and shadaqah (ZIS) through the use of crowdfunding platform. Falah: Jurnal Ekonomi Syariah, 6(1), 30-44. https://doi.org/https://doi.org/10.22219/jes.v6i1.15133

Kholid, M. N. (2018). Keberterimaan muzaki terhadap zakat crowdfunding di Indonesia: preliminary research pendahuluan. CIMAE: Conference on Islamic Management Accounting and Economics, 1(1), 52-58. Diambil dari https://journal.uii.ac.id/CIMAE/article/view/11682

Kim, J. S., Kaye, J., \& Wright, L. K. (2001). Moderating and Mediating Effects in Causal Models. Issues in Mental Health Nursing, 22(1), 63-75. https://doi.org/10.1080/016128401750158768

Kudeshia, C., \& Kumar, A. (2017). Social eWOM: Does it Affect the Brand 
Attitude and Purchase Intention of Brands? Management Research Review, 40(3), 310-330. https://doi.org/10.1108/MRR-07-2015-0161

Kusnendi. (2005). Analisis Jalur Konsep dan Aplikasi dengan Program SPSS dan. Lisrel 8. Bandung: UPI. Bandung: UPI.

Lee, H. H., Fiore, A. M., \& Kim, J. (2006). The role of the technology acceptance model in explaining effects of image interactivity tTechnology on consumer responses. International Journal of Retail and Distribution Management, 34(8), 621-644. https://doi.org/10.1108/09590550610675949

Lee, M. K. O., Shi, N., Cheung, C. M. K., Lim, K. H., \& Sia, C. L. (2011). Consumer's Decision to Shop Online: The Moderating Role of Positive Informational Social Influence. Information and Management, 48(6), 185191. https://doi.org/10.1016/j.im.2010.08.005

Leong, L. W., Ibrahim, O., Dalvi-Esfahani, M., Shahbazi, H., \& Nilashi, M. (2018). The Moderating Effect of Experience on the Intention to Adopt Mobile Social Network Sites for Pedagogical Purposes: An Extension of the Technology Acceptance Model. Education and Information Technologies, 23(6), 24772498. https://doi.org/10.1007/s10639-018-9726-2

Ma, Y. J., Gam, H. J., \& Banning, J. (2017). Perceived ease of use and usefulness of sustainability labels on apparel products: application of the technology acceptance model. Fashion and Textiles, 4(3), 1-20. https://doi.org/10.1186/s40691-017-0093-1

Madjid, I., Ma'ruf, J. J., Ibrahim, M., \& Havizatun, M. (2018). Factors Affecting Online Shopping Attitudes and the Role of Trust as Mediating. International Journal of Management and Economics Invention, 04(09), 1929-1935. https://doi.org/10.31142/ijmei/v4i9.04

Mahaputra, D. G. K., \& Setiawan, P. Y. (2019). Peran Sikap Memediasi Pengaruh Electronic Word of Mouth Terhadap Keputusan Berkunjung. E-Jurnal Manajemen Universitas Udayana, 8(12), 7326. https://doi.org/10.24843/ejmunud.2019.v08.i12.p21

Memon, Y. J., Azhar, S. M., Haque, R., \& Bhutto, N. A. (2019). Religiosity as a moderator between theory of planned behavior and halal purchase intention. Journal of Islamic Marketing, 10(4), 1351-1372.

Muslichah. (2018). The Effect of Self Efficacy and Information Quality on Behavioral Intention with Perceived Usefulness asIntervening Variable. Journal of Accounting - Business \& Management, 25(1), 21-34. https://doi.org/https://doi.org/10.31966/jabminternational.v1i25.327

Nguyen, T. T. H., Nguyen, N., Nguyen, T. B. L., Phan, T. T. H., Bui, L. P., \& Moon, H. C. (2019). Investigating Consumer Attitude and Intention Towards online food Purchasing in an Emerging Economy: An extended TAM approach. Foods, 8(11), 1-15. https://doi.org/10.3390/foods8110576

Niswah, F. M., Mutmainah, L., \& Legowati, D. A. (2019). Muslim Millennial's Intention of Donating for Charity Using Fintech Platform. Journal of Islamic Monetary Economics and Finance, 5(3), 623-644. https://doi.org/10.21098/jimf.v5i3.1080

Pikkarainen, T., Pikkarainen, K., Karjaluoto, H., \& Pahnila, S. (2004). Consumer acceptance of online banking: An extension of the technology acceptance 
model. Internet $\quad$ Research, 224-235. https://doi.org/10.1108/10662240410542652

Purwanto. (2018). Teknik penyusunan instrumen uji validitas dan reliabilitas penelitian ekonomi syariah. Magelang: StaiaPress.

Purwanto, P. (2021). Society Attitudes and Intentions To Use Products In Sharia Bank of Aceh: The Role of Religiosity and Social Influence. ABAC Journal, 41(2), 223-242.

Puskas BAZNAS. (2020). Outlook Zakat Indonesia 2020. Jakarta: Puskas BAZNAS.

Rachbini, W., \& Agustina, A. (2019). Customer style inventory, the usage of Facebook, and purchase intention: are they connected? Jurnal Siasat Bisnis, 23(1), 67-81. https://doi.org/10.20885/jsb.vol23.iss1.art6

Roy, G., Datta, B., \& Mukherjee, S. (2019). Role of electronic word-of-mouth content and valence in influencing online purchase behavior. Journal of Marketing Communications, 25(6), 661-684. https://doi.org/10.1080/13527266.2018.1497681

Roziq, A., Wijayanti, C., \& Irmadariyani, R. (2020). Modification of TAM model application of system of information of management of BAZNAS in Indonesia. International Journal of Scientific and Technology Research, 9(4), 1889-1893.

Sholihin, M., \& Ratmono, D. (2013). Analisis SEM-PLS dengan WarpPLS 3.0 untuk hubungan nonlinier dalam penelitian sosial dan bisnis. Yogyakarta: Andi.

Streukens, S., \& Leroi-Werelds, S. (2016). Bootstrapping and PLS-SEM: A stepby-step guide to get more out of your bootstrap results. European Management Journal, 34(6), 1-15. https://doi.org/10.1016/j.emj.2016.06.003

Sulaeman. (2020). Factors determining behavioral intentions to use Islamic crowdfunding platform in times of Covid-19 in Indonesia: Evidence from TAM approach. Jurnal Ekonomi \& Keuangan Islam, 7(1), 31-44. https://doi.org/10.20885/jeki.vol7.iss1.art3

Sulthon, M. (2015). Dakwah dan sadaqat: Rekonseptualisasi dan rekonstruksi gerakan dakwah awal. Yogyakarta: Pustaka Pelajar.

Tehseen, S., Ramayah, T., \& Sajilan, S. (2017). Testing and Controlling for Common Method Variance: A Review of Available Methods. Journal of Management Sciences, 4(2), 142-168. https://doi.org/10.20547/jms.2014.1704202

Usman, H., Mulia, D., Chairy, C., \& Widowati, N. (2020). Integrating trust, religiosity and image into technology acceptance model: the case of the Islamic philanthropy in Indonesia. Journal of Islamic Marketing, 31(1), 1-49. https://doi.org/10.1108/JIMA-01-2020-0020

Utami, P., Suryanto, T., Nasor, M., \& Ghofur, R. A. (2020). The effect digitalization zakat payment against potential of zakat acceptance in National Amil Zakat Agency. Iqtishadia, 13(2), 216. https://doi.org/10.21043/iqtishadia.v13i2.7809

Venkatesh, V., Morris, M. G., Davis, G. B., \& Davis, F. D. (2003). User Acceptance of Information Technology: Toward a Unified View. MIS Quarterly, 27(3), 
425-478. https://doi.org/10.1006/mvre.1994.1019

Vijayasarathy, L. R. (2004). Predicting consumer intentions to use on-line shopping: The case for an augmented technology acceptance model. Information and Management, 41(6), 747-762. https://doi.org/10.1016/j.im.2003.08.011

Yusfiarto, R., Setiawan, A., \& Nugraha, S. S. (2020). Literacy and Intention to Pay Zakat: A Theory Planned Behavior View Evidence from Indonesian Muzakki. International Journal of Zakat, 5(1), 15-27. https://doi.org/https://doi.org/10.37706/ijaz.v5i1.221

Zhang, K., Cheung, C., \& Lee, M. (2014). Examining the moderating effect of inconsistent reviews and its gender differences on consumers' online shopping decision. International Journal of Information Management, 34(2), 89-98.

Ziadat, M. T. A. L. (2015). Applications of Planned Behavior Theory (TPB) in Jordanian Tourism. International Journal of Marketing Studies, 7(3), 95-106. https://doi.org/10.5539/ijms.v7n3p95 